\title{
ĐÁNH GIÁ ĐÁP ỨNG VÀ TÁC DỤNG KHÔNG MONG MUỐN CỦA PHÁC ĐỒ TC TRONG ĐIỀU TRI BỔ TRỢ TRƯớC UNG THƯ LƯ ỠI TẠI BỆNH VIỆN K
}

\author{
Lê Văn Quảng ${ }^{1,2}$, Ngô Quốc Duy², Ngô Xuân Quý
}

\section{TÓM TẮT}

Mục tiêu: Đánh giá đáp ứng và tác dụng không mong muốn của phác đồ TC trong điều trị bổ trợ trước ung thư lưỡi. Đối tượng nghiên cứu: gồm 125 BN ung thư lưỡi phần di động giai đoạn III, IV $\left(M_{0}\right)$ được điều trị hoá chất bổ trợ trước bằng phác đồ TC tai Bênh viên $K$ từ tháng $1 / 2012$ đến tháng 10/2018. Kết quả: Tỷ lệ đáp ứng hoàn toàn chiếm 14,4\%; đáp ứng 1 phần chiếm 44\%; bệnh giữ nguyên chiếm $36,8 \%$; có $4,8 \%$ BN tiến triển sau 3 đợt. Tỷ lệ đáp ứng của nhóm tuổi $\leq 50$ và $>50$ lần lượt là $61,8 \%$ và $55,7 \%$, nam giới so với nữ giới là $55,1 \%$ và $70,4 \%$. Tỷ lệ đáp ứng ở nhóm chưa di căn hạch và di căn hach tương ứng là $72,9 \%$ và $45,5 \%$, sự khác biệt có ý nghĩa thống kê. Giai đoan III có tỷ lệ đáp ứng cao hơn ở giai đoạn IV, tương ứng là $64,9 \%$ và $55,7 \%$. Thiếu máu chủ yếu gặp ở độ 1 và độ 2 . Tỷ lệ hạ $B C$ nói chung độ 3 , độ 4 lần lượt là $24,3 \%$ và $9,3 \%$. Không có trường hợp nào hạ tiểu cầu độ 3,4. Các tác dung phụ khác như: nôn, buồn nôn, đau cơ, biến chứng thần kinh ngoại vi gặp chủ yếu độ 1,2. Kết luận: Điều trị bổ trợ trước ung thư lưỡi bằng phác đồ TC mang lại tỷ lệ đáp ứng khả quan và có độc tính thấp nhằm mang lại kết quả điều trị tốt cho bệnh nhân ung thư lưỡi giai đoan III, IV (M0).

Tư khóa: Ung thư lưỡi, hóa chất bổ trợ trước, cisplatin, taxane.

\section{SUMMARY}

\section{TO EVALUATE THE RESPONSE AND THE TOXICITY OF THE NEOADJUVANT CHEMOTHERAPY WITH TAXANE PLUS CISPLATIN IN PATIENTS WITH MOBILE TONGUE CANCER AT K HOSPITAL}

Objectives: To evaluate the response rate and the toxicity of the neoadjuvant chemotherapy with taxane plus cisplatin in patients with mobile tongue cancer. Patients and methods: 125 patients with stage III, IV (M0) mobile tongue cancer who were treated neoadjuvant chemotherapy with taxane plus cisplatin at $\mathrm{K}$ hospital from $1 / 2012$ to $10 / 2018$. Results: The complete response rate is $14,4 \%$, partial response rate is $44 \%$, stable disease is 36,5 and progressive disease is $4,8 \%$ after 3 cycles. The response rates for age groups $\leq 50$ and $>50$ are $61.8 \%$ and $55.7 \%$, respectively, and male versus female is $55.1 \%$ and $70.4 \%$. The response rates of

\footnotetext{
1 Trường Đại học Y Hà Nội

${ }^{2}$ Bệnh viện $K$

Chịu trách nhiệm chính: Lê Văn Quảng

Email: lequang@hmu.edu.vn

Ngày nhận bài: 6.01.2021

Ngày phản biện khoa học: 8.3.2021

Ngày duyệt bài: 16.3.2021
}

patients without or with lymph node metastases were $72.9 \%$ and $45.5 \%$, respectively, the difference was statistically significant. Patients with stage III have a higher response rate than patients with stage IV, respectively $64.9 \%$ and $55.7 \%$. Most patients have grades 1, 2 anemia. The grade 3, 4 leucopenia are $24.3 \%$ and $9.3 \%$, respectively. There was no case of grade 3,4 thrombocytopenia. Other side effects: vomiting, nausea, myalgia, peripheral neurological complications, mainly were grade 1,2 . Conclusion: Neoadjuvant chemotherapy with taxane plus cisplatin shows good response and low toxicity, it improves the results of treating patients with stage III, IV(M0) mobile tongue cancer.

Keywods: Mobile tongue cancer, neoadjuvant, cisplatin, taxane.

\section{I. ĐẶT VẤN ĐỀ}

Ung thư lưỡi (UTL) là loại ung thư thường gặp nhất trong các ung thư vùng khoang miệng[1]. Theo GLOBOCAN 2018, hàng năm có khoảng 354.860 ca mắc mới và 177.354 ca tử vong do ung thư khoang miệng với tỷ lệ nam/nữ là 2,27 [1]. Các phương pháp điều trị ung thư lưỡi bao gồm phẫu thuật, xạ trị và hóa chất, tuy nhiên việc lựa chọn phương pháp nào phù hợp phụ thuộc vào giai đoạn bệnh và thể trạng bệnh nhẩn [2]. Tại Việt Nam, tỷ lệ bệnh nhân UTL phát hiện ở giai đoạn muộn (III, IV) còn cao, điều trị giai đoạn này thường khó khăn, cần cá thể hóa và có sự kết hợp nhiều phương pháp điều trị nhằm nâng cao hiệu quả. Một trong những phương pháp đó là điều trị hoá chất bổ trợ trước nhằm hạ thấp giai đoạn bệnh, tạo thuận lợi cho phẫu thuật, xạ trị, làm giảm các biến chứng, hạn chế di căn xa [3]. Trên thế giới, nhiều nghiên cứu đánh giá về vai trò của hoá chất bổ trợ trước ung thư lưỡi cho thấy có nhiều kết quả khả quan, trong đó phác đồ taxane kết hợp với cisplatin có hiệu quả, ít tác dụng không mong muốn hơn so với các phác đồ khác [4],[5]. Tại Việt Nam cho đến nay chưa có nghiên cứu về vai trò của hoá chất bổ trợ trước phác đồ TC trong ung thư lưỡi. Vì vậy chúng tôi thực hiện đề tài này nhằm các mục tiêu sau:

- Đánh giá tỷ lệ đáp ứng của hoá trị bổ trợ trước bằng phác đồ TC trong điều trị ung thư lưỡi giai đoạn III, IV (MO).

- Đánh giá tác dụng không mong muốn của hoá trị phác đồ TC trong điều trị nhóm bệnh nhân trên. 
II. ĐỐI TƯƠNNG VÀ PHƯƠNG PHÁP NGHIÊN CỨU

2.1. Đối tượng nghiên cứu. Gồm $125 \mathrm{BN}$ ung thư lưỡi phẩn di động giai đoạn III, IV (Mo) được điều trị hoá chất bổ trợ trước bằng phác đồ TC tại Bệnh viện $K$ từ tháng 1/2012 đến tháng 10/2018.

\section{Tiêu chuẩn lựa chọn bệnh nhân}

- BN được chẩn đoán ung thư lưỡi phần di động giai đoạn III, IV $\left(M_{0}\right)$ theo phân loại của AJCC năm 2010.

- Thể trạng chung còn tốt (ECOG 0-2)

- Chẩn đoán mô bệnh học tại u là ung thư biểu mô vảy.

- Chức năng tuỷ xương còn tốt, chức năng gan thận còn tốt:

- BN không mắc các bệnh cấp và mạn tính trầm trọng có nguy cơ tử vong trong thời gian gần, không mắc bệnh ung thư khác ngoài bệnh ung thư lưỡi.

Tiêu chuẩn loại trừ: Các BN không thỏa mãn tiêu chuẩn lựa chọn trên

\subsection{Phương pháp nghiên cứu}

Thiết kế nghiên cứu: mô tả

Cỡ mẫu nghiên cứu: gồm 125 BN thỏa mãn tiêu chuẩn lựa chọn và loại trừ

\section{Các biến số nghiên cứu}

- Đặc điểm lâm sàng, cận lâm sàng: tuổi (trên/dưới 50 tuổi), giới (nam/nữ), giai đoạn bệnh (theo TNM), mô bệnh học (theo độ mô học).

- Đánh giá đáp ứng: đáp ứng hoàn toàn, đáp ứng một phần, bệnh giữ nguyên, bệnh tiến triển

- Đánh giá độc tính: độc tính trên hệ tạo huyết (hồng cầu, bạch cầu, tiểu cầu), độc tính

\section{KẾT QUẢ NGHIÊN CỨU}

\section{1. Đánh giá đáp ứng}

Bảng 3.1. Tình trạng đáp ứng sau các chu kỳ hóa chât

\begin{tabular}{|c|c|c|c|c|c|c|c|c|c|}
\hline \multirow{2}{*}{$\begin{array}{c}\text { Tình } \\
\text { trạng đáp } \\
\text { ứng }\end{array}$} & \multicolumn{2}{|c|}{ Hoàn toàn } & \multicolumn{2}{|c|}{ Một phần } & \multicolumn{2}{c|}{$\begin{array}{c}\text { Bệnh giữ } \\
\text { nguyên }\end{array}$} & \multicolumn{2}{|c|}{ Tiến triển } & \multirow{2}{*}{} \\
\cline { 2 - 9 } & BN & $\%$ & BN & $\%$ & BN & $\%$ & BN & $\%$ & \\
\hline Đợt I & 0 & 0 & 31 & 24,8 & 93 & 74,4 & 1 & 0,8 & 125 \\
\hline Đợt II & 0 & 0 & 66 & 52,8 & 58 & 46,4 & 1 & 0,8 & 125 \\
\hline Đợt III & 18 & 14,4 & 55 & 44 & 46 & 36,8 & 6 & 4,8 & 125 \\
\hline Sau 3 đợt & 18 & 14,4 & 55 & 44 & 46 & 36,8 & 6 & 4,8 & 125 \\
\hline
\end{tabular}

\section{Nhân xét:}

- Sau 3 chu kỳ, tỷ lệ đáp ứng hoàn toàn chiếm 14,4\%; đáp ứng 1 phần chiếm 44\%; bệnh giữ nguyên chiếm $36,8 \%$; có 4,8\% BN tiến triển sau 3 đợt.

- Tỷ lệ đáp ứng tăng dần qua các chu kỳ hóa chất.

Bảng 3.2. Tình trang đáp ứng theo tuối, giới sau cả 3 chu kỳ hóa chất

\begin{tabular}{|c|c|c|c|c|c|}
\hline \multirow{2}{*}{ Yếu tố } & \multicolumn{2}{|c|}{ Đáp ứng } & \multicolumn{2}{|c|}{ Không đáp ứng } & \multirow[b]{2}{*}{ p } \\
\hline & BN & $\%$ & $\mathbf{B N}$ & $\%$ & \\
\hline \multicolumn{6}{|c|}{ * Tuối (n=125) } \\
\hline$\leq 50$ & 34 & 61,8 & 21 & 38,2 & $p=0,492$ \\
\hline$>50$ & 39 & 55,7 & 31 & 44,3 & $\mathrm{OR}=1,28$ \\
\hline
\end{tabular}

ngoài hệ tạo huyết (tăng SGOT, SGPT, creatinin), độc tính khác (nôn, mệt mỏi, độc tính thần kinh...)

Các bước tiến hành. Đánh giá lâm sàng và cân lâm sàng trước điều trị

+ Tuổi, giới.

+ Các triệu chứng cơ năng, thực thể, toàn thân.

+ Mô bênh học

+ Giai đoan bênh

Điều trị bằng hoá chất phác đồ TC cho BN đủ tiêu chuẩn:

Docetaxel $75 \mathrm{mg} / \mathrm{m}^{2}$ hoăc Paclitaxel $175 \mathrm{mg} / \mathrm{m}^{2}$, TM, ngày 1.

Cisplatin 100 mg/m², TM, ngày 2 .

Chu kì 21 ngày

Đánh giá kết quả điều trị

+ Đánh giá đáp ứng theo tiêu chuẩn RECIST

1.1: Đánh giá dựa trên lâm sàng và cận lâm sàng (nội soi tai mũi họng, siêu âm cổ, cộng hưởng từ....).

+ Tác dung không mong muốn của hoá chất theo CTCAE 4.0: Độc tính trên hệ tạo huyết và ngoài hệ tạo huyết.

*Các thông tin được mã hoá và xử lý bằng phần mềm SPSS 20.0.

*Các thuâtt toán thống kê:

- Mô tả: trung bình, độ lệch chuẩn, giá trị $x$

- Kiểm định so sánh:

+ Đối với biến định tính sử dụng test so sánh $\chi^{2}$, các so sánh có ý nghĩa thống kề với $p<0,05$. 


\begin{tabular}{|c|c|c|c|c|c|}
\hline \multicolumn{7}{|c|}{ * Giới (n=125) } \\
\hline Nam & 54 & 55,1 & 44 & 45,9 & $\mathrm{p}=0,154$ \\
\cline { 1 - 4 } & 19 & 70,4 & 8 & 39,6 & OR $=0,51$ \\
\hline
\end{tabular}

Nhân xét: - Nhóm tuối $\leq 50$ cho tỷ lệ đáp ứng là $61,8 \%$, tỷ lệ đáp ứng của nhóm tuối $>50$ là $55,7 \%$.

- Tỷ lệ đáp ứng theo giới: nam giới có tỷ lệ đáp ứng là 55,1\%, của nữ giới là 70,4\%.

Bảng 3.3. Đáp ứng theo $T$, N, giai đoạn và độ mô học

\begin{tabular}{|c|c|c|c|c|c|c|}
\hline \multirow{2}{*}{ Giai đoạn } & \multicolumn{2}{|c|}{ Đáp ứng } & \multicolumn{2}{|c|}{ Không đáp ứng } & \multirow{2}{*}{$\begin{array}{c}\text { Tống } \\
\text { BN } \\
\end{array}$} & \multirow[b]{2}{*}{ p } \\
\hline & BN & $\%$ & BN & $\%$ & & \\
\hline \multicolumn{7}{|c|}{$* T(n=125)$} \\
\hline$T_{2}$ & 3 & 25 & 9 & 75 & 12 & \multirow{3}{*}{0,041} \\
\hline$T_{3}$ & 24 & 58,5 & 17 & 41,5 & 41 & \\
\hline $\mathrm{T}_{4}$ & 46 & 63,9 & 26 & 36,1 & 72 & \\
\hline \multicolumn{7}{|c|}{$* N(n=125)$} \\
\hline $\mathbf{N}_{0}$ & 43 & 72,9 & 16 & 27,1 & 59 & \multirow{2}{*}{$p=0,002$} \\
\hline $\mathbf{N}_{1,2,3}$ & 30 & 45,5 & 36 & 55,5 & 66 & \\
\hline \multicolumn{7}{|c|}{ * Giai đoạn (n=125) } \\
\hline III & 24 & 64,9 & 13 & 36,1 & 37 & \multirow{2}{*}{$p=0,342$} \\
\hline IV & 49 & 55,7 & 39 & 44,3 & 88 & \\
\hline \multicolumn{7}{|c|}{ * Đô mô hoc (n=125) } \\
\hline I & 10 & 52,6 & 9 & 47,4 & 19 & \multirow{3}{*}{$p=0,853$} \\
\hline II & 46 & 59,7 & 31 & 40,3 & 77 & \\
\hline III & 17 & 58,6 & 12 & 41,4 & 29 & \\
\hline
\end{tabular}

Nhân xét: - Tỷ lệ BN đáp ứng ở giai đoạn T4 là 63,9\%; T3 là 58,5\%

- Tỷ lệ đáp ứng ở nhóm di căn hạch và chưa di căn hạch tương ứng là $72,9 \%$ và $45,5 \%$

- Giai đoạn III có tỷ lệ đáp ứng cao hơn ở giai đoạn IV, tương ứng là $64,9 \%$ và $55,7 \%$

- Tỷ lệ đáp ứng ở độ mô học II chiếm 59,7\%; độ III là 58,6\%; độ I chiếm tỷ lệ 52,6\%.

\subsection{Tác dụng không mong muốn}

Bảng 3.4. Tác dụng không mong muốn trên huyêt học

\begin{tabular}{|c|c|c|c|c|c|c|c|c|c|c|c|}
\hline & \multicolumn{2}{|c|}{ Độ 0} & \multicolumn{2}{|c|}{ Độ I } & \multicolumn{2}{|c|}{ Độ II } & \multicolumn{2}{|c|}{ Độ III } & \multicolumn{2}{|c|}{ Độ IV } & \multirow[t]{2}{*}{$\boldsymbol{\Sigma}$} \\
\hline & BN & $\%$ & BN & $\%$ & BN & $\%$ & BN & $\%$ & BN & $\%$ & \\
\hline \multicolumn{12}{|c|}{ Huyêt săc tố } \\
\hline Đợt I & 74 & 59,2 & 43 & 34,4 & 5 & 4,0 & 3 & 2,4 & 0 & 0 & 125 \\
\hline Đợt II & 61 & 48,8 & 42 & 33,6 & 19 & 15,2 & 3 & 2,4 & 0 & 0 & 125 \\
\hline Đợt III & 54 & 43,2 & 44 & 35,2 & 24 & 19,2 & 3 & 2,4 & 0 & 0 & 125 \\
\hline \multicolumn{12}{|c|}{ Bạch câu } \\
\hline Đợt I & 57 & 45,6 & 14 & 11,2 & 18 & 14,4 & 37 & 29,6 & 12 & 9,6 & 125 \\
\hline Đợt II & 50 & 40,0 & 17 & 13,6 & 19 & 15,2 & 26 & 20,8 & 13 & 10,4 & 125 \\
\hline Đợt III & 57 & 45,6 & 13 & 10,4 & 17 & 13,6 & 28 & 22,4 & 10 & 8 & 125 \\
\hline \multicolumn{12}{|c|}{ Bạch câu hạt } \\
\hline Đợt I & 30 & 24,0 & 15 & 12,0 & 17 & 13,6 & 35 & 28,0 & 28 & 22,4 & 125 \\
\hline Đợt II & 33 & 26,4 & 16 & 12,8 & 12 & 9,6 & 31 & 24,8 & 33 & 26,4 & 125 \\
\hline Đợt III & 32 & 25,6 & 13 & 10,4 & 19 & 15,2 & 29 & 23,2 & 32 & 25,6 & 125 \\
\hline \multicolumn{12}{|c|}{ Tiếu câu } \\
\hline Đợt I & 108 & 86,4 & 16 & 12,8 & 1 & 0,8 & 0 & 0 & 0 & 0 & 125 \\
\hline Đợt II & 106 & 84,8 & 19 & 15,2 & 0 & 0 & 0 & 0 & 0 & 0 & 125 \\
\hline Đợt III & 108 & 86,4 & 17 & 13,6 & 0 & 0 & 0 & 0 & 0 & 0 & 125 \\
\hline
\end{tabular}

Nhận xét: - Hạ HST chủ yếu gặp ở độ 1 và độ 2; độ 3 gặp 9 trường hợp chiếm 2,4\%; không có BN nào ở đô 4.

- Hạ BC độ 3 gặp ở 91/375 chu kỳ, chiếm 24,3\%. Hạ BC độ 4 gặp 6,7\%.

- Hạ BC hạt độ 3 đợt I, II, III gặp với tỷ lệ tương ứng là $28 \% ; 24,8 \%$ và $23,2 \%$. Hạ $\mathrm{BC}$ hạt độ 4 đợt I,II,III tưong ứng là $22,4 \% ; 26,4 \%$ và $25,6 \%$.

- Không ghi nhận được trường hợp nào hạ tiểu cầu độ 3,4 qua các chu kỳ hoá chất. 
VIETNAM MEDICAL JOURNAL N²2 - MARCH - 2021

Bảng 3.5. Tác dụng không mong muốn trên gan, thận theo từng chu kỳ điều trị

\begin{tabular}{|c|c|c|c|c|c|c|c|c|c|c|c|}
\hline \multirow[t]{2}{*}{ ten } & \multicolumn{2}{|c|}{ Độ 0} & \multicolumn{2}{|c|}{ Độ I } & \multicolumn{2}{|c|}{ Độ II } & \multicolumn{2}{|c|}{ Độ III } & \multicolumn{2}{|c|}{ Độ IV } & \multirow[b]{2}{*}{$\Sigma$} \\
\hline & BN & $\%$ & BN & $\%$ & BN & $\%$ & BN & $\%$ & BN & $\%$ & \\
\hline \multicolumn{12}{|c|}{ SGOT } \\
\hline Đợt I & 98 & 78,4 & 26 & 20,8 & 1 & 0,8 & 0 & 0 & 0 & 0 & 125 \\
\hline Đợt II & 109 & 87,2 & 16 & 12,8 & 0 & 0 & 0 & 0 & 0 & 0 & 125 \\
\hline Đợt III & 118 & 94,4 & 7 & 5,6 & 0 & 0 & 0 & 0 & 0 & 0 & 125 \\
\hline \multicolumn{12}{|c|}{ SGPT } \\
\hline Đợt I & 100 & 80 & 25 & 20 & 0 & 0 & 0 & 0 & 0 & 0 & 125 \\
\hline Đợt II & 111 & 88,8 & 14 & 11,2 & 0 & 0 & 0 & 0 & 0 & 0 & 125 \\
\hline Đợt III & 117 & 93,6 & 8 & 6,4 & 0 & 0 & 0 & 0 & 0 & 0 & 125 \\
\hline \multicolumn{12}{|c|}{ Creatinin } \\
\hline Đợt I & 122 & 97,6 & 3 & 2,4 & 0 & 0 & 0 & 0 & 0 & 0 & 125 \\
\hline Đợt II & 120 & 96,0 & 5 & 4,0 & 0 & 0 & 0 & 0 & 0 & 0 & 125 \\
\hline Đợt III & 116 & 92,8 & 9 & 7,2 & 0 & 0 & 0 & 0 & 0 & 0 & 125 \\
\hline Buồn nôn & 34 & 27,2 & 39 & 31,2 & 25 & 20 & 27 & 21,6 & 0 & 0 & 125 \\
\hline Nôn & 61 & 48,8 & 24 & 19,2 & 18 & 14,4 & 22 & 17,6 & 0 & 0 & 125 \\
\hline Đau co & 110 & 88,0 & 8 & 6,4 & 2 & 1,6 & 0 & 0 & 0 & 0 & 125 \\
\hline Thân kinh & 78 & 62,4 & 41 & 32,8 & 6 & 4,8 & 0 & 0 & 0 & 0 & 125 \\
\hline Mệt mỏi & 20 & 16,0 & 89 & 71,2 & 16 & 12,8 & 0 & 0 & 0 & 0 & 125 \\
\hline
\end{tabular}

Nhận xét: - Tỷ lệ tăng SGOT, SGOT, Creatinin chủ yếu gặp độ I. Chỉ có 1 BN có tăng SGOT độ II.

- Tỷ lệ buồn nôn, nôn, đau cớ, biến chứng thần kinh, mệt mỏi gặp chủ yếu ở độ I, II.

\section{BÀN LUÂ̂N}

4.1. Tình trạng đáp ứng. Điều trị hoá chất tân bổ trợ là điểu trị hoá chất trước phẫu thuât hoặc xạ trị nhằm mục đích thu nhỏ tổn thương để phẫu thuật và xạ trị thuận lợi hơn. Hoá chất bổ trợ trước đem lại tỷ lệ đáp ứng tại chỗ cao, nâng cao khả năng dung nạp thuốc cho người bệnh, giảm tỷ lệ kháng thuốc và ngăn ngừa di cắn xa xuất hiện sớm. Trong điều trị ung thư đầu mặt cổ giai đoạn muộn, Cisplatin vẫn là thuốc được sử dụng rộng rãi nhất và cũng là loại thuốc tỏ ra có hiệu quả. Dựa trên nền tảng phác đồ có Cisplatin, và kết quả của các nghiên cứu trên thế giới, chúng tôi kết hợp thêm với Taxane (Palitaxel hoăc Docetaxel) với mục đích giúp bệnh nhân có tỷ lệ đáp ứng cao mà vẫn có khả năng dung nạp thuốc tốt.

Đáp ứng chung: Trong nghiên cứu của chúng tôi, sau chu kỳ hoá chất đầu tiên chỉ có 31 bệnh nhân đáp ứng một phần chiếm tỷ lệ $24,8 \% ; 74,4 \%$ bệnh giữ nguyên và có $1 \mathrm{BN}$ tiến triển. Tình trạng đáp ứng tăng dần qua các chu kỳ điều trị hoá chất. Tính đáp ứng sau cả 3 chu kỳ: ĐƯHT là 14,4\%; ĐƯMP là 44\%; bệnh giữ nguyên là $36,8 \%$; bệnh tiến triển là $4,8 \%$. Theo tác giả Lê Văn Quảng (2013) nghiên cứu hiệu quả phác đồ $\mathrm{CF}$, kết quả cho thây tỷ lệ ĐƯHT là $12 \%$; ĐƯMP là $50,4 \%$; bệnh giữ nguyên là $30,8 \%$; bệnh tiến triển là $6,8 \%$ [6]. Theo Stefano và cộng sự (2011) nghiên cứu 43 bệnh nhân ung thư đầu cổ giai đoạn IV(M0) điều trị hoá chất TC bổ trợ trước, sau 3 chu kỳ TC, có tới 9 bệnh nhân đáp ứng hoàn toàn (chiếm tới 20,9\%), 23 bệnh nhân đáp ứng một phần (chiếm 53,5\%)[7]. Tác giả Rajesh và cộng sự (2018) cũng nghiên cứu trên 70 bệnh nhân ung thư khoang miệng ở giai đoạn T4, có 56 bệnh nhân được dùng phác đồ TC, tỷ lệ đáp ứng toàn bộ là $30,4 \%$. Tỷ lệ đáp ứng ở hai nghiên cứu này thấp hơn theo nghiên cứu của chúng tôi, lý do có thể là tác giả Patil và Rajesh chỉ tập trung ở nhóm bệnh nhân có giai đoạn T4 [5].

Đáp ứng theo tuổi, giới: Chúng tôi chia thành hai nhóm tuổi trên và dưới 50 tuổi để so sánh. Nhóm tuổi $\leq 50$ cho tỷ lệ đáp ứng là $61,8 \%$, cao hơn so với nhóm tuổi > 50 là $55,7 \%$. Tuy nhiên sự khác biệt về tình trạng đáp ứng giữa hai nhóm tuổi không có ý nghĩa thống kê với $\mathrm{p}=0,189$. Nghiên cứu của Phạm Cẩm Phương cho thấy không có sự khác biệt về tình trang đáp ứng giữa hai nhóm tuổi và tình trạng đáp ứng và giới[8]. Nghiên cứu của Lewin (1997) khi nghiên cứu trên 461 bệnh nhân UT biểu mô vảy đầu mặt cổ thây tỷ lệ đáp ứng không phụ thuộc vào tuổi và giới.

Đáp ứng theo giai đoạn: nghiên cứu của chúng tôi, tỷ lệ đáp ứng của giai đoạn III là $64,8 \%$, của giai đoạn IV là $55,7 \%$. Có sự khác biệt về mức độ đáp ứng giữa các giai đoạn $\mathrm{T}$ và $N$ với $p<0,05$. Theo Lê Văn Quảng (2013) tỷ lệ đáp ứng khi sử dụng phác đồ CF ở giai đoạn III và IV tương ứng là $75 \%$ và $56,7 \%$. Tác giả cũng 
nhận định rằng những bệnh nhân có hạch cổ trên lâm sàng khi điều trị hóa chất thì u thường đáp ứng tốt hơn so với hạch [6]. Stefano (2011) khi nghiên cứu phác đồ Paclitxel và Cisplatin tân bổ trợ trên các bệnh nhân ung thư biểu mô vảy vùng đầu cổ giai đoạn IV báo cáo tỷ lệ đáp ứng sau 3 chu kỳ hóa chất với giai đoạn này là $74,4 \%$. Tác giả cho rằng tỷ lệ đáp ứng trong nghiên cứu của mình cao hơn so với một số nghiên cứu khác có thể do số chu kỳ hóa chất sử dụng và liều Paclitaxel trong nghiên cứu cao hơn[7].

Tình trạng đáp ứng theo độ mô học: Theo nghiên cứu của Okada (2010) độ mô học của khối u là một trong các yếu tố tiên lượng của ung thư biểu mô vảy của lưỡi. Độ mô học của khổi $u$, xâm nhập mạch máu và lympho liển quan đến tình trạng di căn hạch với $p<0,05$. Ensley (1984) nghiên cứu 164 bệnh nhân ung thư đầu cổ bằng phác đồ $C F$, tỷ lệ đáp ứng ở nhóm mô học biệt hóa cao, biêtt hóa vừa và biêt hóa kém tương ứng là $75 \%, 71 \%$ và $66 \%$. Nghiên cứu của chúng tôi, độ mô học II và III có tỷ lệ đáp ứng lần lượt là $59,8 \%$ và $58,6 \%$ cũng tương tự với kết quả của các tác giả kể trên.

4.2. Tác dụng không mong muốn. Điều trị bệnh nhân ung thư lưỡi ngoài mục tiêu kéo dài thời gian sống thêm cho bệnh nhân, chất lượng cuộc sống của bệnh nhân, tác dụng không mong muốn gây ra do phương pháp điều trị cũng là một mục tiêu hết sức quan trọng. Các tác dụng phụ được ghi nhận trong nghiên cứu của chúng tôi:

Trên hệ huyêt học. Nghiên cứu của chúng tôi, trong tổng số 375 chu kỳ điều trị hoá chất: có 129 chu kỳ có hạ HST độ 1 (chiếm 34,4\%), có 48 bệnh nhân hạ HST độ 2 (chiếm 12,8\%), độ 3 gặp 9 trường hợp chiếm 7,2\%; không có $\mathrm{BN}$ nào ở độ 4 . Tỷ lệ hạ $\mathrm{BC}$ nói chung độ 3 , độ 4 lần lượt là $24,3 \%$ và $9,3 \%$; trong đó hạ $\mathrm{BC}$ hạt độ 3, 4 lần lượt là $25,3 \%$ và $24,8 \%$. Tỷ lệ hạ tiểu câu cả 3 chu kỳ là $14,1 \%$ (trong đó đô 1 là $13,9 \%$; độ 2 là $0,2 \%$; không có trường hợp nào ở độ 3 và 4).

Trong nghiên cứu pha III E1395 do tác giả Gibson và công sự (2005) so sánh đối đầu hiêuu quả và tác dụng không mong muốn của hai phác đồ $C F$ và $T C$ trên 280 bệnh nhân ung thư biểu mô vảy vùng đầu cổ giai đoạn muộn được chia làm 2 nhóm. Tỷ lệ hạ HST độ 3,4 ở nhóm được điều trị CF lần lượt là $31 \%$ và $2 \%$. Trong khi đó tỷ lệ tương ứng ở nhóm được điều trị TC là $9 \%$ và $4 \%$, sự khác biệt có ý nghĩa thống kê. Cũng trong nghiên cứu này, tỷ lê bênh nhân hạ $\mathrm{BC}$ đô 3,4 lân lượt là $27 \%$ và $8 \%$. Tỷ lệ hạ $\mathrm{BC}$ hạt độ̉
3,4 lần lượt là 25 và 30\%), tỷ lệ bệnh nhân hạ tiểu cầu độ 3,4 lần lượt là $3 \%$ và $1 \%$. Khi so sánh với $\mathrm{CF}$, phác đồ TC có vẻ ít tác dụng không mong muốn hơn trên hạ bạch cầu và hạ tiểu cầu. Tác giả Gibson báo cáo tỷ lệ hạ $\mathrm{BC}$ hạt, hạ tiểu cầu độ 3,4 khi dùng CF tương ứng lần lượt là $27 \%, 40 \%$ và $17 \%, 6 \%$ [9]. Nghiên cứu khác của Basaran (2013), điều trị TC trên 50 bệnh nhân ung thư vảy vùng đầu cổ tái phát di căn, hạ tiểu câu ít gặp, chủ yếu gặp độ 1,2 (3,9\% và $1 \%$ ), độ 3 gặp 1\%; độ 4 gặp 1\%. Như vậy, tỷ lệ hạ HST, BC, tiểu cầu ở nhóm bênh nhân được dùng TC trong nghiên cứu của chúng tôi tương tự với các kết quả của các tác giả khác trên thế giới và thấp hơn nhóm bệnh nhân được dùng $\mathrm{CF}$ trong điều trị tân bổ trợ.

Các động tính trển gan, thận. Đa số các thuốc hoá chất đều được chuyển hoá ở gan và được thải trừ qua thận, nên hai cơ quan này là một trong những cơ quan ảnh hưởng tác dụng không mong muốn nhiều nhất của hoá chất. Đồng thời, đây cũng là vẫn đề lâm sàng ảnh hưởng trực tiếp đến liệu trình điều trị của bệnh nhân. Tuy nhiên, phác đồ TC ít ảnh hưởng đến tăng men gan. Trong nghiên cứu của chúng tôi, tăng SGOT chỉ gặp ở độ II trong đợt I với tỷ lệ 0,8\%. Đa số tăng ở mức độ I: Đợt I $(20,8 \%)$, đợt II $(12,8 \%)$, đợt III $(5,6 \%)$.

Kết quả của chúng tôi cho thây không có trường hợp nào tăng creatinin ở độ 2,3,4. Tăng creatinin gặp ở độ 1 qua các đợt là: Đợt I $(2,4 \%)$, đợt II $(4,0 \%)$, đợt III $(7,2 \%)$. Tác tác giả nước ngoài cùng cho kết quả tương tự. Trong nghiên cứu pha III E1395 của tác giả Gibson và cộng sự (2005), tăng men gan độ 3, 4 ở nhóm bệnh nhân được điều trị TC chỉ có 3 bênh nhân trên tổng số 108 bệnh nhân được điều trị. Không có trường hợp nào độ 4 [9]. Nhìn chung tác dụng không mong muốn trên hệ huyết học và gan, thận ít không có bệnh nhân nào tác dụng phụ gây nguy hiểm nặng đến tính mạng.

Trong nghiên cứu của chúng tôi, các độc tính như nôn, buồn nôn, mệt mỏi hay biến chứng thần kinh ngoại vi ít gặp, chủ yếu độ I,II. Không có $\mathrm{BN}$ nào phải dừng điều trị hay có biến cố bất lợi liên quan đến độc tính.

\section{KẾT LUẬN}

- Sau 3 chu kỳ, tỷ lệ ứng hoàn toàn chiếm $14,4 \%$; đáp ứng 1 phần chiếm $44 \%$; bệnh giữ nguyên chiếm $36,8 \%$; có $4,8 \%$ BN tiến triển sau 3 đợt.

- Hạ HST chủ yếu gặp ở độ 1 và độ 2. Hạ BC hạt độ 3 đợt I, II, III gặp với tỷ lệ tương ứng là 
$28 \% ; 24,8 \%$ và 23,2\%. Ha BC hạt độ 4 đợt I, II, III tương ứng là $22,4 \% ; 26,4 \%$ và $25,6 \%$.

- Các tác dụng phụ khác như: nôn, buồn nôn, đau cớ, biến chứng thần kinh ngoại vi gặp chủ yếu độ 1,2 .

\section{TÀI LIÊU THAM KHẢO}

1. Bray F, Ferlay J, Soerjomataram I, et al (2018). Global cancer statistics 2018: GLOBOCAN estimates of incidence and mortality worldwide for 36 cancers in 185 countries. CA Cancer J Clin, 68(6): 394-424.

2. Zanoni DK, Montero $\mathbf{P H}$, Migliacci JC, et al (2019). Survival outcomes after treatment of cancer of the oral cavity (1985-2015). Oral Oncol, 2019. 90: 115-121.

3. Chi A.C, T.A. Day, and B.W. Neville (2015). Oral cavity and oropharyngeal squamous cell carcinoma--an update. CA Cancer J Clin, 65(5): 401-21.

4. Ma J, Liu $Y$, Yang $X$, et al (2013). Induction chemotherapy in patients with resectable head and neck squamous cell carcinoma: a meta-analysis. World J Sura Oncol, 11: 67.

5. Vijay M. Patil, Vanita Noronha, Amit Joshi, et al (2015). Compliance With Neoadjuvant Chemotherapy in T4 Oral Cancers: Place, Person, Socioeconomic Status, or Assistance. J Glob Oncol, 1(2): 65-72.

6. Lê Văn Quảng (2013). Nghiên cứu điều trị ung thư lưỡi giai đoan III, IV (M0) bằng cisplatin - 5FU bố trớ trước phấu thuất và/hoặc xạ trị. Luận án tiến sĩ. Trườnq Đai hoc Y Hà Nôi.

7. Pergolizzi S, Santacaterina A, Adamo B, et al (2011). Induction chemotherapy with paclitaxel and cisplatin to concurrent radiotherapy and weekly paclitaxel in the treatment of locoregionally advanced, stage IV (M0), head and neck squamous cell carcinoma. Mature results of a prospective study. Radiat Oncol, 6: 162.

8. Phạm Cẩm Phương (2005). Đánh giá hiêuu quả của hoá chất tân bô trớ phác đồ CF trong điều trì ung thư lưỡi giai đoan İII, IV (M0) tại bênh viên K từ năm $2002-2005$, Luân văn tốt nghiêp bác sĩ nôi trú, Trườna Đai hoc v Hà Nôi.

9. Gibson MK, Li Y, Murphy B, et al (2005). Randomized phase III evaluation of cisplatin plus fluorouracil versus cisplatin plus paclitaxel in advanced head and neck cancer (E1395): an intergroup trial of the Eastern Cooperative Oncology Grou J Clin Oncol, 2005. 23(15): 3562-7.

\title{
ĐÁNH GIÁ KẾT QUẢ HÓA XA TRI ĐỒNG THỜI TRIẸT CĂN UNG THƯ CỔ TỬ CUNG GIAI ĐOẠN III TẠI BỆNH VIỆN K
}

\author{
Trương Công Minh ${ }^{1}$, Võ Văn Xuân²
}

\section{TÓM TẮT}

Muc tiêu: Đánh giá kết quả hóa xa trị đồng thời triệt căn ung thư cổ tử cung giai đoạn III tại bệnh viện $\mathrm{K}$ và một số tác dụng không mong muốn của phác đồ trên nhóm bệnh nhân nghiên cứu. Đối tương và phương pháp nghiên cứu: Nghiên cứu mồ tả hồi cứu có theo dỗi dọc trên 76 bệnh nhân ung thư cổ tử cung (UTCTC) giai đoan III (FIGO 2018) tại bệnh viện $\mathrm{K}$, được xạ trị khung chậu bằng kĩ thuật 3DCRT đồng thời với hóa chất phác đồ Cisplatin hàng tuần, theo sau đó là xa trị áp sát suất liều cao tứ tháng $1 / 2017$ đến tháng $12 / 2018$. Tiêu chí chính là tỷ lệ sống thêm không bệnh (DFS) 3 năm, tiêu chí phụ là các độc tính muộn của phác đồ. Kết quả: Tỷ lệ sống thêm không bệnh 3 năm là $67,5 \%$. U xâm lấn âm đạo $1 / 3$ dưới, đường kính ngắn hạch chậu $\geq 15 \mathrm{~mm}$, di cằn hạch cạnh động mạch chủ bụng là các yếu tố độc lập liển quan đến DFS. Tỷ lệ độc tính muộn độ 1,2 và độ 3,4 trên tiêu hóa và tiết niêuu lần lượt là $44,7 \%$; 18,4\%; 9,2\%; 2,6\%. Kết luận: Hóa xạ trị đồng thời triệt căn trên bệnh nhân UTCTC giai đoạn III với xa trị

${ }^{1}$ Trường Đại học Y Hà Nội

²Bênh viên $K$

Chịu trách nhiệm chính: Trương Công Minh

Email: truongcongminh.hmu@gmail.com

Ngày nhận bài: 7.01.2021

Ngày phản biên khoa hoc: 8.3.2021

Ngày duyệt bài: 16.3 .2021 áp sát suất liều cao đem lại tỷ lệ sống thêm không bệnh 3 năm khả quan trong khi các độc tính muộn trền hê tiêu hóa, tiết niệu ở mức chấp nhần được.

Tư khóa: Ung thư cổ tử cung, giai đoạn III, hóa xạ đồng thời triệt căn, DFS 3 năm

\section{SUMMARY}

\section{EVALUATION OF TREATMENT RESULTS OF} DEFINITIVE CONCURRENT

CHEMORADIOTHERAPY IN STAGE III CERCICAL CANCER PATIENTS AT K HOSPITAL

Objectives: The aims of our study were to evaluate the result of concurrent chemoradiotherapy in FIGO III cervical cancer patients and late toxicities of this treatment method. Patients and Methods: 76 patients stage III cervical cancer (FIGO 2018) with good performance status (PS 0-2) were treated with three-dimensional conformal radiation therapy (3D CRT) combined with chemotherapy (weekly Cisplatin regimen), followed by computed tomoqraphy-quided high-dose-rate (HDR) brachytherapy. The primary end point was 3-year disease-free survival rate and proqnosis factors, secondary end points were late toxicities of this treatment. Result: The 3-year DFS for the 76 eliqible patients was $67.5 \%$. On multivariate analyses, invasion of the lower third of vaqina, short axis of pelvic lymph node diameter of $\geq 15 \mathrm{~mm}$, paraaortic lymph node metastasis were identified as adverse prognostic factors for DFS in stage III cervical 